\title{
Agaricomycetes (Basidiomycota, Fungi) diversity in a protected area in the Maracaju Mountains, in the Brazilian central region
}

\author{
Vera Lucia Ramos Bononi ${ }^{1,2,3}$, Ademir Kleber Morbeck de Oliveira ${ }^{1}$, Adriana de Melo Gugliotta ${ }^{2}$ and \\ Josiane Ratier de Quevedo ${ }^{1}$
}

Received: 11.08.2016; accepted: 10.05.2017

\begin{abstract}
Agaricomycetes (Basidiomycota, Fungi) diversity in a protected area in the Maracaju Mountains, in the Brazilian central region). The fungi diversity in Brazil is not fully known yet, mainly in Serra de Maracaju, which is located in the central portion of the State of Mato Grosso do Sul, in the center-western region of Brazil. Samples were taken from different phytophysiognomies of the Cerrado, the dominating biome of that region, in areas where Cerrado and pasture alternate, in the municipality of Corguinho. Of the species identified, 18 are new citations for Brazil, as they are not included in the List of Brazilian Flora (fungi), and 36 are recorded for the first time for [the State of] Mato Grosso do Sul. As a total, 62 species were collected in nine excursions during 2014 and 2015. Out of this total, 15 species are deemed edible, four are toxic, ten are medicinal, two are used in bioremediation processes, and one is bioluminescent, according to the literature. Keywords: basidiomycetes, biodiversity, conservation, fungi, savannah
\end{abstract}

RESUMO - (Diversidade de Agaricomicetos (Basidiomycota, Fungi) em uma área protegida nas Montanhas de Maracaju, na região central do Brasil). A diversidade dos fungos brasileiros ainda não é totalmente conhecida, principalmente na Serra de Maracaju, localizada na região central do Estado de Mato Grosso do Sul, no centro-oeste do Brasil. Coletas foram realizadas em diferentes fitofisionomias do Cerrado, bioma predominante na região, no município de Corguinho, em áreas onde o cerrado e pastagens se alternam. Dezoito das espécies identificadas são primeira citação para o Brasil e não se encontram relacionadas na lista da flora do Brasil (fungos) e 36 são citadas pela primeira vez para Mato Grosso do Sul, de um total de 62 espécies coletadas em nove excursões realizadas durante os anos de 2014 e 2015. Deste total 15 espécies coletadas são consideradas comestíveis, quatro tóxicas, 10 medicinais, duas utilizadas em processos de biorremediação e uma bioluminescente, segundo a literatura.

Palavras-chave: basidiomicetos, biodiversidade, cerrado, conservação, fungos

\section{Introduction}

The Maracaju Mountains, $900 \mathrm{~m}$ altitude on average, are located in the central region of Mato Grosso do Sul State $\left(23^{\circ} 15^{\prime} \mathrm{S}, 55^{\circ} 31^{\prime} \mathrm{W} ; 17^{\circ} 34^{\prime} \mathrm{S}\right.$, $\left.54^{\circ} 45^{\prime} \mathrm{W}\right)$, dividing it in the north-south direction, acting as a watershed between High Paraguay River Basin to the west, and High Paraná River Basin to the east.

The region is located in the core area of the Cerrado domain in its southern part, being covered with many different physiognomies. Among them we can mention arboreal cerrado, shrubland cerrado, clean and dirty grassland, seasonal forests (with loss of leaves), riparian forests (in the margins of water courses) and meadows, a riparian formation dominated by Buriti palms (Mauritia flexuosa Mart.).

The presence of the city and large cattle farms with exotic grasses, mainly Urochloa spp. in the region, have led to great anthropogenic influence due the presence of Eucalyptus spp., sugarcane (Saccharum officinarum L.) and soybean (Glicyne $\max (\mathrm{L}$.$) Merrill) plantations, among other crops.$ However, natural fragmented remnants are still found in areas in the region where there are many places with continuous areas of preserved habitats. That occurs especially on the slopes of mountains and other isolated sites.

Brazil has been known to have one of the most significant biodiversity in the world. However,

1. Universidade Anhanguera/UNIDERP, Rua Ceará 333, caixa postal 2153, 79003-010 Campo Grande, MS, Brazil

2. Instituto de Botânica de São Paulo, Av. Miguel Estefano 3.687, 04301-902 São Paulo, SP, Brazil

3. Corresponding author: vbononi@uol.com.br 
existing data on biological diversity are limited to some types of organisms, mainly superior plants and vertebrates spread in institutions, museums and scientific collections in the country and abroad.

Assessments of the Brazilian biodiversity conducted in Brazil (Bicudo \& Menezes 1996, Siqueira \& Joly 1996, Canhos 1997, Joly \& Bicudo 1998) counted about 2500 macroscopic fungi species. A few were recorded for the region or for the State of Mato Grosso do Sul. According to Maia \& Carvalho Jr. (2015), for the State 116 fungi species have been listed divided into 66 families and 21 orders of the Classes Ascomycota, Basidiomycota, Blastocladiomycota, Chytridiomycota and Glomeromycota. Out of that total, 45 species are Agaricomycetes, 21 out of which occur in savannah areas.

Up to this date, in the cerrado biome, including areas in Mato Grosso (Sampaio 1916) and São Paulo (Fidalgo et al. 1965, Bononi 1984, Gugliotta 1997, Baseia \& Milanez 2001a,b, 2002a,b, 2003, Baseia 2005, Baseia et al. 2007), a total of 95 species have been mentioned (Gibertoni \& Drechsler-Santos 2010).

This paper intends to broaden the knowledge of Brazilian biodiversity in a Maracaju Mountains located in the central region of Mato Grosso do Sul State, southwestern Brazil, showing its abundance and potential, completing data in the list of the Brazilian Flora, fungi, prepared by the Botanical Garden of Rio de Janeiro, IBAMA (Maia \& Carvalho Jr. 2015). The assessment and vouchers deposited in the national herbarium enable future molecular biology studies to confirm the diversity and phylogenetic connections among the species found.

\section{Material \& methods}

Study Area - The study site was the area in the Maracaju Mountains located in the central region of Mato Grosso do Sul State, southwestern Brazil, with samples taken from different types of vegetation in the cerrado, the dominating biome occurring in the Taboco region, municipality of Corguinho, Mato Grosso do Sul, Brazil.

The region altitude is $320 \mathrm{~m}$ on average and, according to Köppen \& Geiger, the climate is tropical (Aw) with dry winters and rainy summers, with a temperature of $24,8{ }^{\circ} \mathrm{C}$ on average and annual rainfall of $1444 \mathrm{~mm}$ on average (Secretaria de Planejamento e Coordenação Geral de Mato Grosso do Sul 1990).

The collection region is located in the Chaqueno morphoclimatic domain in the sub-region cerrado
(Morrone 2001), with predominance of the cerrado phytophysiognomy, stricto sensu, and presence of forest formations in the cerrado, where there are arboreal species such as Caryocar brasiliense Camb. (pequi), Copaifera langsdorffii Desf. (copaíba), Lafoensia pacari A. St./Hil. (pacari), Siphoneugena densiflora Berg. (maria-preta), Vochysia haenkeana Mart. (escorrega-macaco), Xylopia aromatica (Lam.) Mart. (pimenta-de-macaco), Agonandra brasiliensis Miers ex Benth \& Hook. f. (pau-marfim), Bowdichia virgilioides Kunth. (sucupira-preta), Dimorphandra mollis Benth. (faveiro), Qualea grandiflora Mart. (pau-terra-grande), Callisthene fasciculata Mart. (jacaré-da-folha-grande), Dilodendron bippinatum Radlk. (maria-pobre), Luehea paniculata Mart. \& Zucc. (açoita-cavalo), Dipteryx alata Vog. (baru), Pseudobombax tomentosum (Mart. \& Zucc.) A.Robyns (imbiruçu), Terminalia argentea Mart. \& Zucc. (capitão-do-campo), among others.

In the unique shrubby cerrado habitat we can find, for instance, Callistene major Mart. (Itapicuru), Qualea parviflora Mart., Lafoensia pacari (dedaleira), Caryocar brasiliense (pequi), Kielmeyera coriacea Mart. \& Zucc. (pau-santo), Hymenaea stigonocarpa Mart. ex Hayne (jatobá), Hancornia speciosa B.A. Gomes (mangabeira), Palicourea rigida Kunth (chapéu-de-couro), Tabebuia serratifolia (Vahl) G. Nicholson (ipê), Syagrus flexuosa (Mart.) Becc. (ariri), Licania humilis Cham. \& Schltdl. (oiti), Stryphnodendron obovatum Benth. (barbatimão), Casearia sylvestris Sw. (pau-de-espeto) and Norantea guianensis Aubl (flor de papagio).

The forest vegetation over small water courses (gallery woods) has species such as Protium heptaphyllum (Aubl.) March (breu, almécega), Psychotria carthagenensis Jacq. (erva-de-gralha), Schefflera morototoni (Aubl.) Maguire, Steyerm. \& Frodin (morototó), Tapirira guianensis Aubl. (pombeiro), Virola sebifera Aubl. (virola), Xylopia sericea St. Hill. (pimenta-de-macaco), Nectandra cissiflora Nees (louro), Maclura tinctoria (L.) D. Don. ex Steud. (amoreira), Rapanea ferruginea (Ruiz \& Pav.) Mez. (copororoca), Cecropia lyratiloba Miq. (cecropia), Calophyllum brasiliensis Camb. (guanandi), Alibertia edulis A. Rich. (marmelada), Inga nobilis Willd. (inga) and Guarea guidonia (L.) Sleumer. (marinheiro).

However, most part of the region has pastures planted with Urochloa humidicola (Rendle) Morrone \& Zuloaga, which dominate at flatter sites.

Collections - Only macroscopic fungi were collected, which were deposited in the herbarium of the Botanical 
Institute of São Paulo (SP). Nine collection excursions were undertaken in the months of March, April, May, June, August, September, October, November and December 2014. Collectors were Ademir Kleber Morbeck de Oliveira, Richard Matheus Fernandes and Bruno Carlos Feliciano de Lima Silva.

The collection, preservation and herborization followed the standardized techniques for fungi (Fidalgo \& Bononi 1984). Identification was based on micro and macrostructure of the basidiome accordingly to the recommendations of Teixeira (1962, 1995), Gilbertson \& Ryvarden (1986), and Ryvarden $(1991,2004)$. Nomenclature and classification system followed those used by Kirk et al. (2008), Index Fungorum (www.indexfungorum.org), and Mycobank and related databases (www.mycobank.org). Taxa are mentioned in alphabetic order, families and species of Agaricomycetes. Geographic distribution in Brazil was based on the List of Brazilian Flora, fungi (Gugliotta et al. 2015). The species cited for Brazil for the first time are marked with 1 asterisk and those cited for the first time for the State of Mato Grosso do Sul, with 2 asterisks. Descriptions of the species cited for the first time for Brazil and photographs (all taken by Ademir Kleber Morbeck de Oliveira) have been included in this paper.

Species identified

Agaricales

Agaricaceae

**Agaricus porosporus Heinem. Kew Bulletin 15(2): 235. 1961.

Material examined: BRAZIL. Mato Grosso do Sul: Maracaju Mountains, Corguinho, 12-XI-2014, A.K.M. Oliveira et. al. (SP466255).

Previously cited for Brazil, São Paulo and known from Martinica, Trinidad and Venezuela (Pegler 1997).

**Chlorophyllum rhacodes (Vittad.) Vellinga, Mycotaxon 83: 416. 2002.

Material examined: BRAZIL. Mato Grosso do Sul: Maracaju Mountains, Corguinho, 14-XI-2014, A.K.M. Oliveira et. al. (SP466256).

Edible when cooked, toxic when raw (Kuo 2015). Previously cited for Brazil, in Rio Grande do Sul, and for North America (Rick 1961).
**Lepiota cristata (Bolton) P.Kumm. Der Führer indie Pilzkunde 137. 1871.

Material examined: BRAZIL. Mato Grosso do Sul: Maracaju Mountains, Corguinho, 14-XI-2014, A.K.M. Oliveira et. al. (SP466257).

Cosmopolitan, suspected of being toxic and causing gastrointestinal problems (Lincoff 1981). Cited by Rick $(1937,1961)$ for Brazil, Rio Grande do Sul.

\section{Arachniaceae}

**Arachnion album (Schwein.) Schrift, Naturforsch. Ges, Leipzig 1: 59. 1922.

Material examined: BRAZIL. Mato Grosso do Sul: Maracaju Mountains, Corguinho, 14-VI-2014, A.K.M. Oliveira et. al. (SP466258).

Cosmopolitan, inedible (Kasuya et al. 2006). Previously cited for Brazil, RS, São Leopoldo (Rick 1908).

\section{Bolbitiaceae}

**Bolbitius vitellinus (Pers.) Fr., Epicrisis Systematis Mycologici 254. 1838.

Material examined: BRAZIL. Mato Grosso do Sul: Maracaju Mountains, Corguinho, 14-V-2014, A.K.M. Oliveira et. al. (SP466343).

Cosmopolitan, inedible and toxic. Cited for Brazil, in the State of São Paulo (Pegler 1997).

*Conocybe crispa (Longyear) Singer, Lilloa 22: 485. 1951.

Figure 1

Material examined: BRAZIL. Mato Grosso do Sul: Maracaju Mountains, Corguinho, 15-V-2014, A.K.M. Oliveira et. al. (SP466260).

Cited to North America and Europe, there is no record of that species for Brazil.

Description: basidiome with pilei centrally stipitate, conical, reddish and grayish brown, covered with very small hairs when young, 1.5-2.0 cm diâm., with flat margin; adnate lamellae, whitish to grayish, branched, narrow, irregularly contorted,;erect stipe, white, 0.4-0.5 cm diâm.; basidiospores hyaline, cylindrical to alantoid, 3-4 × 1-1.5 $\mu \mathrm{m}$. On dead trunks at pastures. 

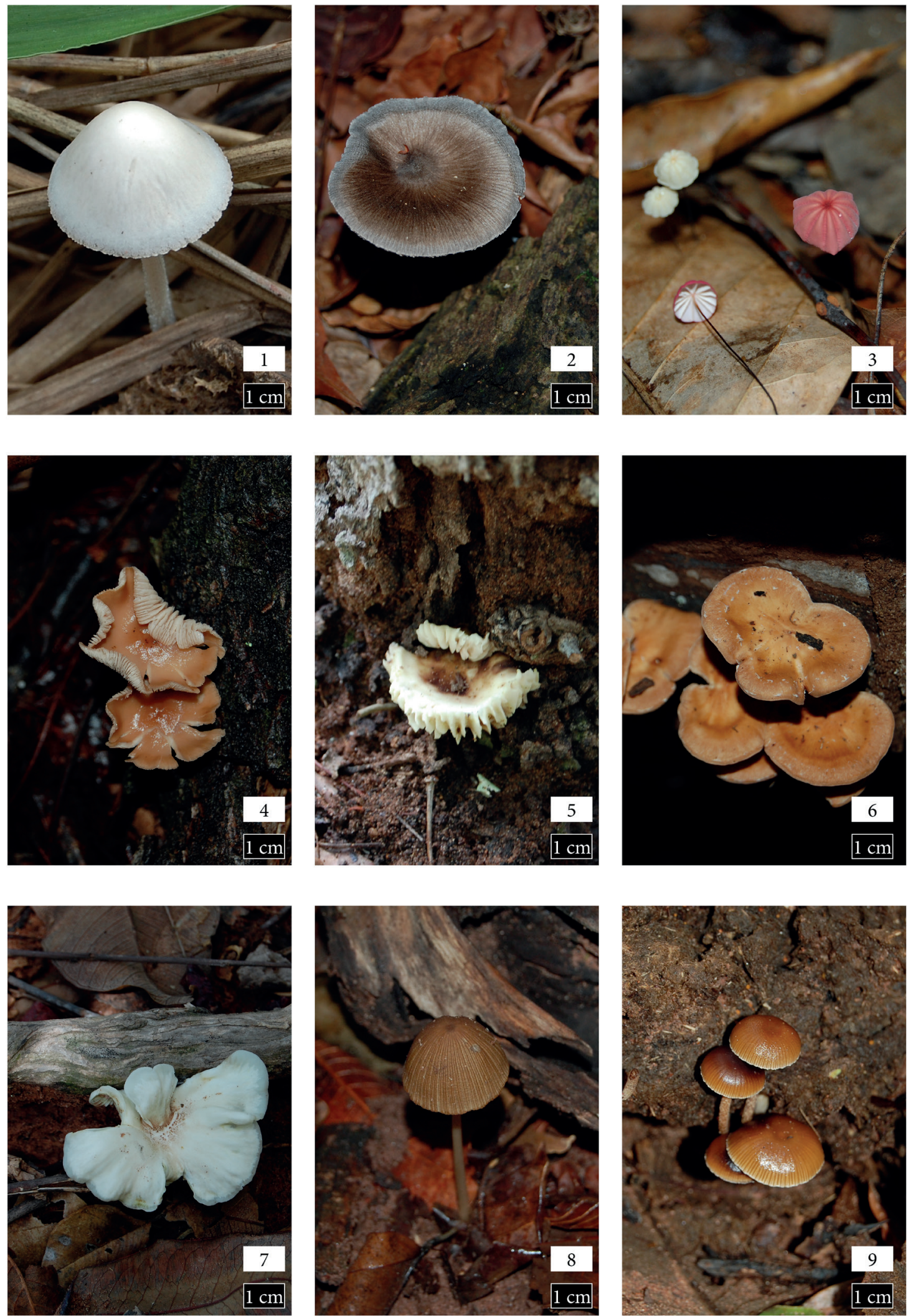

Figures 1-9. Agaricomycetes of the Maracaju Mountains, Mato Grosso do Sul State, Brazil. 1. Conocybe crispa. 2. Gymnopus dryophilus. 3. Marasmius androsaceus. 4. Marasmius oreades. 5. Mycena pura. 6. Rhodocollybia butyraceae. 7. Pleurotus eryngii. 8. Coprinellus micaceus. 9. Panaeolus rickenii. 


\section{Coprinaceae}

**Coprinus jamaicenses Murrill, Mycologia 10(2): 84. 1918.

Material examined: BRAZIL. Mato Grosso do Sul: Maracaju Mountains, Corguinho, on cattle manure, 15-V-2014, A.K.M. Oliveira et. al. (SP466261 e SP466337).

Occurrence in Jamaica, Trinidad, Brazil, in Ilha do Cardoso and tropical North America (Capelari 1989).

Cortinariaceae

**Gymnopilus arenicola Hesler, North American species of Gymnopilus. Mycological Memoirs 3: 69. 1969.

Material examined: BRAZIL. Mato Grosso do Sul: Maracaju Mountains, Corguinho, 12-XII-2014, A.K.M. Oliveira et. al. (SP466262).

Previously collected in Brazil, Ilha do Cardoso (Capelari 1989).

**Gymnopilus earley Murrill, Mycologia 5(1): 22. 1913.

Material examined: BRAZIL. Mato Grosso Do Sul: Maracaju Mountains, Corguinho, 12-XII-2014, A.K.M. Oliveira et. al. (SP466263).

Species known from Jamaica, previously cited for Brazil in the State of São Paulo and Rio Grande do Sul. It may cause allergies (Capelari et al. 2015).

**Pyrrhoglossum stipitatum Sing., Sydowia 2(1-6). 1948.

Material examined: BRAZIL. Mato Grosso do SuL: Maracaju Mountains, Corguinho, 26-VI-2014, A.K.M. Oliveira et. al. (SP466264).

Known from Central America (Singer 1951) and Brazil, Ilha do Cardoso (Capelari 1989), but it is not included in the list of the Brazilian Flora (fungi).

\section{Lycoperdaceae}

**Morganella puiggarii (Speg.) Kreisel\& Dring, Reprium nov.Spec. Regni veg.74: 116. 1967.

Material examined: BRAZIL. Mato Grosso Do Sul: Maracaju Mountains, Corguinho, 26-VI-2014, A.K.M. Oliveira et. al. (SP466267) e 12-XII-2014 (SP466268).
Previously cited for Brazil, in the State of São Paulo (Leon 1971).

\section{Marasmiaceae}

*Gymnopus dryophilus (Bull.). Murrill, N. Amer. Fl. 9(5): 362. 1916.

Figure 2

Material examined: BRAZIL. Mato Grosso do SuL: Maracaju Mountains, Corguinho, 12-XII-2014, A.K.M. Oliveira et. al. (SP466269, SP466280).

Occurs at temperate woods in Europe and North America. It is usually saprophyticus, but it may attack living trees. It contains anti-inflammatory glucan. The hat (pilei) is edible, but its stipe is toxic (PachecoSanchez et al. 2006). It is the first citation to Brazil and is not included in the List of fungi in Brazil.

Description: basidiome with centrally stipitate pilei, convex and flattened when old, meaty, yellowish brown, 2.5-6.0 cm diâm. with flat margin; narrow adnate lamellae, close to each other and many, white to light beige; flat stipe, white a little darker at the base where it is covered with white mycelium, $3-8 \times 0.2-0.6 \mathrm{~cm}$, with constant diameter; elliptic basidiospores hyaline, smooth, 5-7 × 3-3.5 $\mu \mathrm{m}$. On rotten wood.

*Marasmius androsaceus (L.) Fr., Epicrisis Systematis Mycologici 385. 1838.

Figure 3

Material examined: BRAZIL. Mato Grosso Do SuL: Maracaju Mountains, Corguinho, 12-XII-2014, A.K.M. Oliveira et. al. (SP466270, SP466271, SP466272, SP466273, SP466274, SP466275, SP466276, SP466277).

The most collected species in this area. It occurs in Europe and the United State (Antonin \& Nordeloos 2010). It is the first citation to Brazil and not included in the List of fungi of Brazil.

Description: basidiome with centrally stipitate pilei, flattened, dry, very thin, pinkish brown, depressed at the center, 0.4-1.2 cm diâm.; margin from furrowed to radially wrinkled; adnate lamellae, well separated, whitish; hard, dry stipe, smooth, lighter near the hat and black afterwards, hollow; elliptic basidiospores, smooth, hyaline, $6-9 \times 2.5-3.5 \mu \mathrm{m}$. It grows in groups on burlap. 
**Marasmius bellus Berk., Hooker's J. Bot. Kew Gard. Misc. 8: 139. 1856.

Material examined: BRAZIL. Mato Grosso do SuL: Maracaju Mountains, Corguinho, 12-XI-2014, A.K.M. Oliveira et. al. (SP466278).

Occurs in north and northeast of Brazil (Singer 1976) and in São Paulo (Pegler 1997, Puccinelli \& Capelari 2009).

*Marasmius oreades (Bolton) Fr., Epicrisis Systematis Mycologici 375. 1836.

Figure 4

Material examined: BRAZIL. Mato Grosso do Sul: Maracaju Mountains, Corguinho, 13-XI-2014, A.K.M. Oliveira et. al. (SP466279).

Cosmopolitan, edible, used to make biscuits and soaps, contains trehalose sugar and has been used in mycoremendiation of soils polluted with bismuth (Elekes \& Busuioc 2010). It was not cited to Brazil and included in the list of fungi species.

Description: basidiome with centrally stipitate pilei, convex to bell shaped, dry, smooth, light beige to brown when old, 2-6 cm diâm., with furrowed margin; adnexed lamellae, almost free, well separate, light beige; hard, dry, stipe, brownish at the top and darker at the base which has very small hairs, $3-7 \times 0.3-0.5 \mathrm{~cm}$ with constant diameter; elliptic basidiospores, smooth, hyaline to light beige, 7-10 $\times 4-6 \mu \mathrm{m}$. Occurs in lawns, in groups and it has an agreeable smell.

**Neonothopanus gardnerii (Berk. ex Gardner) Capelari, Desjardin, Perry, Asi. Stevani, Mycologia 103(6): 1435. 2011.

Material examined: BRAZIL. Mato Grosso do Sul: Maracaju Mountains, Corguinho, 13-XI-2014, A.K.M. Oliveira et. al. (SP466299).

It is cosmopolitan, edible and bioluminescent (Eyssartier \& Roux 2013). Currently, due to data of molecular biology, there have been discussions on the delimitation of the species and on its geographic distribution. Brazil has been cited at several sites (Capelari et al. 2011).

\section{Mycenaceae}

*Mycena pura (Pers.) P. Kumm., Der Führer in die Pilzkunde 107. 1871.

Figure 5
Material examined: BRAZIL. Mato Grosso do Sul: Maracaju Mountains, Corguinho, 12-XI-2014, A.K.M. Oliveira et. al. (SP466334).

Cosmopolitan, it has paraquinonic acid, a sesquiterpenoid that induces mammals' cells to differentiate in granulocyte or macrophage (cell of the HL60 line). It also has estrogen-bilirubin D, anti-fungi compound (Becker et al 1997). It is not cited before and included in the list of fungi species of Brazil.

Description: basidiome with conical to convex pilei when old, firm, humid, smooth, light beige-pinkish, 2-5 cm diâm., straight margin, white, furrowed; adnate or adnexed lamellae, sparse, with veins between them, light beige sometimes with a light lilac shade; dry, smooth stipe, sometimes furrowed, pilei concolor or lighter, 3-10 $\times 0.2-0.6 \mathrm{~cm}$, constant diameter or larger at the base; elliptic narrow basidiospores, hyaline, smooth, amyloid in Melzer solution, 6-10 × 3-3.5 $\mu \mathrm{m}$; abundant cystidia at the lamellas' margins, lageniform with long neck, 40-100 × 10-25 $\mu \mathrm{m}$. On foliage.

\section{Nidulariaceae}

**Cyathus stercoreus (Schwein.) De Toni, Syll. Fung.7: 40. 1888.

Material examined: BRAZIL. Mato Grosso do Sul: Maracaju Mountains, Corguinho, on cattle manure, 12-XI-2014, A.K.M. Oliveira et. al. (SP466282).

In the Chinese medicine it is used against strong stomachaches. It degrades lignin, which increases digestibility of animal food due to the action of laccase enzymes and manganese peroxidase. It degrades TNT (Chen 1995). Previously mentioned in the south and southeast of Brazil (Baseia \& Milanez 2003).

\section{Omphalotaceae}

*Rhodocollybia butyraceae (Bull:Fr.) Lennox, Mycotaxon 9: 219. 1979.

Figure 6

Material examined: BRAZIL. Mato Grosso do SuL: Maracaju Mountains, Corguinho, 14-XI-2014, A.K.M. Oliveira et. al. (SP466281).

Common in North America and edible (Kirk et al. 2008), this is the first citation to Brazil.

Description: basidiome with pilei centrally stipitate, convex, reddish brown, 3-4 cm diâm.; convolute margin and pilei concolor; lamellae tied to the stipe 
or free, white sometimes with pink shades, with margins irregularly dented; stipe wider at the base, white top and then reddish brown, hollow when old, 4-6 × 0.5-2 cm; dextrinoid basidiospores, smooth, elliptic, light yellowish brown, 5-6 × 3-4 $\mu \mathrm{m}$; pleurocystidia absent, small cheilocystidia, sub-clubshaped with irregular projections, up to $35 \mu \mathrm{m}$ long. On foliage.

\section{Physalacriaceae}

Oudemansiella canarii ( Jungh.) Höhn, Sber. Akad. Wiss. Wien, Math/naturw.K1.Abt.1, 118: 276. 1909.

Material examined: BRAZIL. Mato Grosso do Sul: Maracaju Mountains, Corguinho, 27-VI-2014, A.K.M. Oliveira et. al. (SP466283).

Common in Brazil, edible, cultivable (Capelari \& Maziero 1988, Ruegger et al. 2001).

\section{Pleurotaceae}

*Pleurotus eryngii (DC.) Quél., Mémoires de la Société d'Émulation de Montbéliard, Ser. 2(5): 112. 1872.

Figure 7

Material examined: BRAZIL. Mato Grosso do Sul: Maracaju Mountains, Corguinho, 27-XI-2014, A.K.M. Oliveira et. al. (SP466284).

Occurs in the Mediterranean Europe, Middle East and North Africa. It is edible and cultivated in Asia (Estrada \& Royse 2008). It is not cited and included in the list of fungi species of Brazil.

Description: basidiome with eccentrically stipitate pilei, dry, smooth, brown, 1.5-3 cm diâm.; smooth and flat margin and pilei concolor; decurrent lamellae, white, meaty stipe, solid, white, bulging at the base, $5-6 \times 1.5-5 \mathrm{~cm}$; hyaline basidiospores, smooth, elliptic, $4-5 \times 2.5-3.5 \mu \mathrm{m}$. On dead trees' trunks.

**Pleurotus pulmonarius (Fr.) Quél., Mémoires de la Société d'Émulation de Montbéliard, Sér. 2(5): 11. 1872.

Material examined: BRAZIL. Mato Grosso do Sul: Maracaju Mountains, Corguinho, 27-XI-2014, A.K.M. Oliveira et. al. (SP466288, SP466339).

Occurs on coniferous and angiosperms, broadly distribute in the east of the United State and in temperate and subtropical regions. Edible. It has beta-d-glucan polysaccharides with anti-oxidizing, antimycotic, anti-inflammatory, anti-diabetes and analgesic properties. It is also used against cancer and against hay fever (Ramesh \& Pattar 2010). Found in Brazil, in São Paulo, Paraná and Rio Grande do Sul (Menolli Jr. et al. 2014).

\section{Psathyrellaceae}

*Coprinellus micaceus (Bull.: Fr.) Vilgalys, Hopple \& Jack. Johson \& Jacq. Johnson, Taxon 50 (1): 234. 2001.

Figure 8

Material examined: BRAZIL. Mato Grosso do Sul: Maracaju Mountains, Corguinho, 27-XII-2014, A.K.M. Oliveira et. al. (SP466285).

The species has antibacterial enzymes and is edible (Efremenkova et al. 2003). It was not citated and included in the list of species of Brazil.

Description: basidiome with centrally stipitate pilei, conic and bell shaped when old, dry, reddish brown covered with small shining particles that disappear in older specimens, meaty, 3-6 cm diâm.; furrowed margin pilei concolor; adnexed lamellae, numerous, near each other, white, darkening when old; shining white stipe, hollow, 1.5-0.7 $\times 0.3-0.6 \mathrm{~cm}$ with constant diameter; smooth basidiospores with apical pore, dark brown, 7-10 $\times 3.5-5 \mu \mathrm{m}$. Occurs in groups on burlap.

*Panaeolus rickenii Hora, Transactions of the British Mycological Society 43(2): 454. 1960.

Figure 9

Material examined: BRAZIL. Mato Grosso do Sul: Maracaju Mountains, Corguinho, 12-XI-2014, A.K.M. Oliveira et. al. (SP466286).

It is the first citation to Brazil and it is not included in the list of fungi of Brazil.

Description: basidiome with centrally stiptate pilei, conic, bell shaped when old, dry, smooth, light brown, 2-3 cm diâm., fragile; very smooth margin, pilei concolor; lamellae adnate to stipe, close to each other, gray to black; smooth stipe, up to $10 \mathrm{~cm}$ long, 0.1-0.2 cm diâm., constant; very dark brown to black basidiospores in $\mathrm{KOH}$, with apical pore, subglobose, smooth, 10-15 × 8-11 $\mu \mathrm{m}$; pleurocystidium absent; ventricose fusiform to irregularly cylindrical cheilocystidium, $35 \times 10 \mu \mathrm{m}$; hymeniform pileipellis, with pileicystides. At pastures. 


\section{Schizophyllaceae}

**Schizophyllum commune Fr., Systema Mycologicum 1: 330. 1821.

Material examined: BRAZIL. Mato Grosso do Sul: Maracaju Mountains, Corguinho, 27-VI-2014, A.K.M. Oliveira et. al. (SP466287).

It is cosmopolitan and was found in several sites in Brazil. There is no previous record for Mato Grosso do Sul (Capelari \& Maziero 1988).

\section{Strophariaceae}

*Hypholoma fasciculare ( Huds.) P. Kumm., Der Führer in die Pilzkunde 72. 1871.

Figure 10

Material examined: BRAZIL. Mato Grosso do Sul: Maracaju Mountains, Corguinho, 27-VI-2014, A.K.M. Oliveira et. al. (SP466288).

There is no previous record of the species for Brazil.

Description: basidiome with centrally stipitate pilei, convex, hemispheric, meaty, smooth, yellow with orange center, with whitish margin, 2-4 cm diâm.; numerous lamellae, close to each other, adnate or free, initially light yellow and darkening to greenish gray, frequent shorter lamellae are present; stipe with unclear or partial ring, light yellow with darker stains mainly near the base, diameter almost constant a little wider at the base, $6-8 \times 0.5 \mathrm{~cm}$; ellipsoid basidiospores, smooth, with apical pore, dark brown to almost black, $5-8 \times 3-4.5 \mu \mathrm{m}$; fusiform-ventricose pleuro-chrysocystidium $40 \times 10 \mu \mathrm{m}$; skin-type pileipellis with embedded elements. It grows in wisps in the soil on burlap.

**Psilocybe brasiliensis Guzmán, Mycotaxon 7(2): 234. 1978.

Material examined: BRAZIL. Mato Grosso do Sul: Maracaju Mountains, Corguinho, 13-XI-2014, A.K.M. Oliveira et. al. (SP466340).

It has neotropical distribution and presents hallucinogenic activity because it contains psilocybin. It was previously cited for Brazil in the State of São Paulo (Guzmán 1978).

**Psilocybe castanella Peck, Bull. New York State Mus. Nat.Hist. 1(2): 7. 1887.
Material examined: BRAZIL. Mato Grosso do SuL: Maracaju Mountains, Corguinho, 13-XI-2014, A.K.M. Oliveira et. al. (SP466289).

Itdegrades pentachlorophenol and hexachlorobenzene. It is not included in the list of fungi species of Brazil, but it was mentioned for the State of São Paulo (Matheus 1998).

\section{Tricholomataceae}

*Clitocybe infundibuliformis( Schaeff.) Quél., Mémoires de la Société d'Émulation de Montbéliard 5: 88. 1872.

Figure 11

Material examined: BRAZIL. Mato Grosso DO SuL: Maracaju Mountains, Corguinho, 12-XII-2014, A.K.M. Oliveira et. al. (SP466290).

It occurs in North America and Europe (Massee 1899). It is not cited to Brazil.

Description: basidiome with centrally stipitate pilei, infundibuliform, thin, meaty and hard, light beige, $5 \times 4 \mathrm{~cm}$, with wavy margin and pilei concolor; decurrent lamellae, numerous, firm, white to light beige; hard stipe, smooth, slightly sinuous at the base, 3-8 $\times 0.5-1 \mathrm{~cm}$; elliptic basidiospores, smooth, hyaline, $6-7 \times 3,5-4,5 \mu \mathrm{m}$. On rotten wood.

*Tricholoma argyraceum (Bu11.) Gillet, Hyménomycètes (Alençon) 103. 1874.

Figure 12

Material examined: BRAZIL. Mato Grosso do Sul: Maracaju Mountains, Corguinho, 23-V-2014, A.K.M. Oliveira et. al. (SP466291).

Known as ectomycorrhiza in Europe. Its edibility is arguable (Jordan \& Michael 2004). It is not cited to Brazil before.

Description: basidiome with umbonate pilei, centrally stiptate, with small light grayish scales, 3-7 $\times 5-8 \mathrm{~cm}$, with serrated margin, gray; white lamellae, numerous, adnate; erect stipe, constant diameter slightly wider at the base, smooth, 4-6 $\times 1-1.5 \mathrm{~cm}$; cylindrical basidiospores, hyaline 4-5 × 1.5-2 $\mu \mathrm{m}$. On wood.

Auriculariales

Auriculariaceae

Auricularia mesenterica (Dicks.) Pers., Mycol. eur. (Erlanga) 1: 97. 1822.

Material examined: BRAZIL. Mato Grosso do SuL: Maracaju Mountains, Corguinho, 12-XII-2014, A.K.M. Oliveira et. al. (SP466293). 

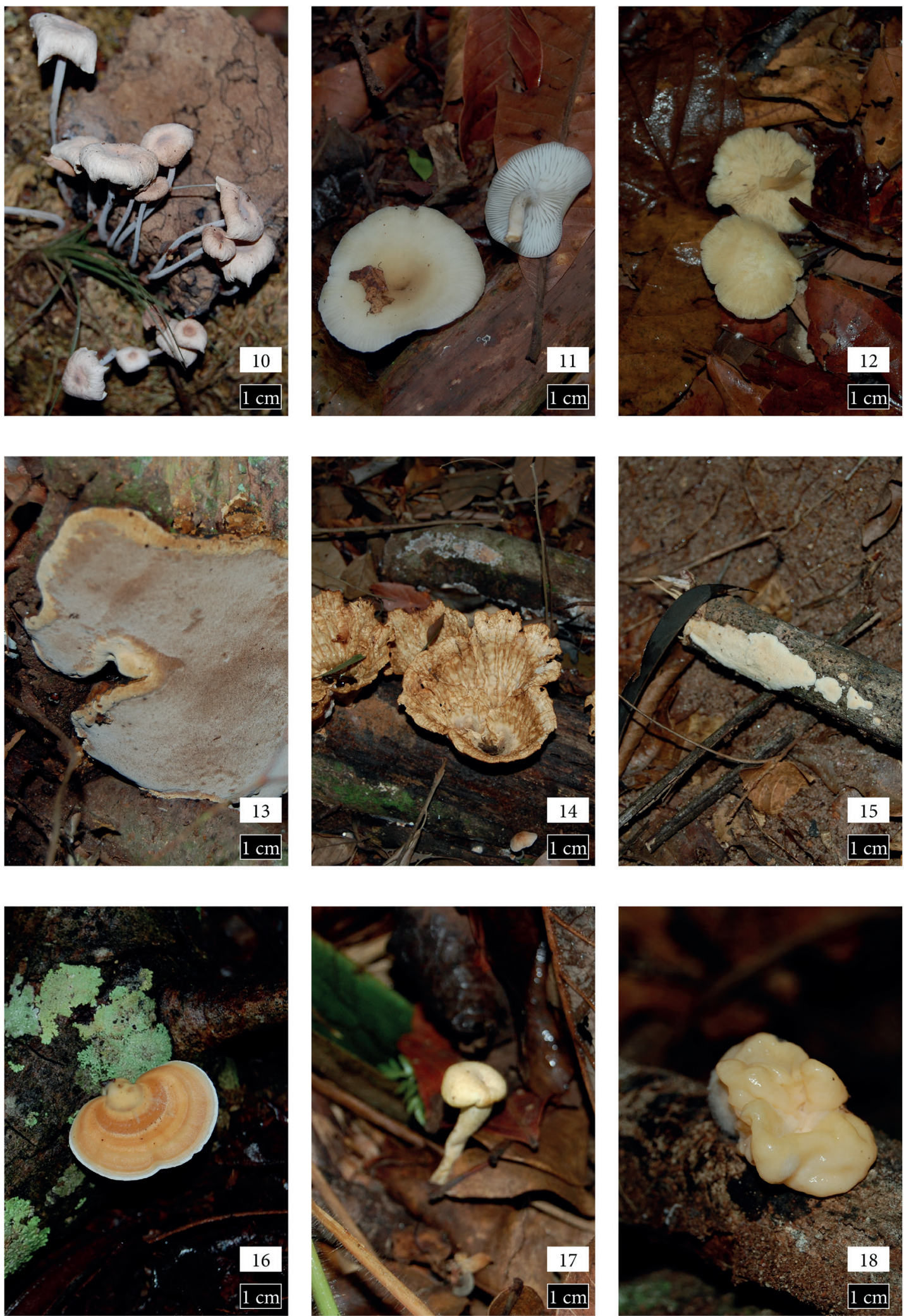

Figures 10-18. Agaricomycetes of the Maracaju Mountains, Mato Grosso do Sul State, Brazil. 10. Hypholoma fasciculare. 11. Clitocybe infundibuliformis. 12. Tricholoma argyraceum. 13. Fomitiporia robusta. 14. Cymatoderma elegans. 15. Athelopsis galzinii. 16. Trametes ellipsospora. 17. Guepinia helvelloides. 18. Tremella mesenterica. 
Edible species, common in Brazil (Teixeira 1945, Baseia \& Goes-Neto 2006).

Auricularia polytricha (Mont.) Sacc., Atti Inst. Veneto

Sci. lett., ed Arti, Sér. 3(3): 722. 1885.

Material examined: BRAZIL. Mato Grosso do SuL: Maracaju Mountains, Corguinho, 27-VI-2014, A.K.M. Oliveira et. al. (SP466294, SP466295, SP466296, SP466297).

It is edible and has anti-cholesterol and anticoagulant properties. Frequent all over Brazil (Jesus 1996, Dreschler-Santos 2008).

\section{Clavulinaceae}

**Clavulina cinerea (Bull.) J. Schröt. in Cohn, Krypt./ Fl. Schlesien (Breslau) 3.1(25-32): 443. 1888.

Material examined: BRAZIL. Mato Grosso do Sul: Maracaju Mountains, Corguinho, 13-XI-2014, A.K.M. Oliveira et. al. (SP466300).

It occurs in the soil or on litter, it is edible and cited for Brazil (Corner 1950).

**Clavulina coralloides (L.) J. Schröt., in Cohn, Krypt./Fl. Schlesien (Breslau) 3.1(25-32): 443. 1888.

Material examined: BRAZIL. Mato Grosso do Sul: Maracaju Mountains, Corguinho, 12-XII-2014, A.K.M. Oliveira et. al. (SP466341).

It is edible and occurs in the soil or on roots. It is the only fungus that contains alpha-parinaric acid. The species was cited for Brazil in Amazon as C. cristata (Gibertoni et al. 2015) and for the States of São Paulo and Rio Grande do Sul (Baltazar \& Gibertoni 2009).

Hymenochaetales

Hymenochaetaceae

*Fomitiporia robusta (P. Karst.) Fiasson \& Niemela, Taxon 24: 25. 1984.

Figure 13

Material examined: BRAZIL. Mato Grosso do SuL: Maracaju Mountains, Corguinho, 14-XI-2014, A.K.M. Oliveira et. al. (SP466301).

It is a fungus used mixed with other to protect bees. That mix increases bees' resistance to diseases, to pesticides, pollution and draught. It also improves pollination and honey production. It is de first occurrence to Brazil and not cited in the list of species of fungi of Brazil.
Description: effuse reflex basidiome, tending to globose, very hard, 10-12 cm diâm.; abhymenial surface with smooth rind, zoned and grooved concentrically, very dark brown, with obtuse and yellowish margin; hymenial porous surface, brown, 3-4 pores per mm, circular pores; hard context rusty brown, black in $\mathrm{KOH}$, up to $1 \mathrm{~cm}$ thick; dimitic hyphal system with generative hyphae with thin walls, hyaline, simple sept (without clamp connection) 4-5 $\mu \mathrm{m}$ diâm. and skeletal hyphae with thickened wall, a little branched, brown, 5,5-6 $\mu$ m diâm.; globose basidiospores, smooth, hyaline, 5-6 $\mu$ diâm.; irregular fusiform arrows present in hymenium, thickened wall, brown (it becomes black in $\mathrm{KOH}$ ) $40-50 \times 2-10 \mu \mathrm{m}$. On rotten wood.

**Hydnochaete badia Bres., Hedwigia 35: 287. 1896.

Material examined: BRAZIL. Mato Grosso Do Sul: Maracaju Mountains, Corguinho, 12-XII-2014, A.K.M. Oliveira et. al. (SP466303).

Known only in Brazil: Bahia, Minas Gerais, São Paulo, Paraná and Rio Grande do Sul (Bononi 1982). It is not mentioned in the list of fungi species of Brazil.

Fuscoporia gilva (Schwein.) T. Wagner and M. Fisch., Mycologia 94(6): 1013. 2002.

Material examined: BRAZIL. Mato Grosso do Sul: Maracaju Mountains, Corguinho, 26-VI-2014, A.K.M. Oliveira et. al. (SP466302, SP466306).

Cosmopolitan species, inedible. Its polysaccharides inhibit the growth of melanomas in mice (Bae et al. 2005). The species is common in Brazil, it is included in the list of Flora species as Phellinus gilvus (Schwein.) Pat.

**Fulvifomes merrillii ( Murril) Baltazar;Gilbertoni, Mycotaxon 111: 206. 2010.

Material examined: BRAZIL. Mato Grosso do Sul: Maracaju Mountains, Corguinho, on partially alive trees, 26-VI-2014, A.K.M. Oliveira et. al. (SP466304).

Neotropical, cited for Brazil and Costa Rica, it has anti-oxidizing properties (Drescheler-Santos et al. 2009).

**Phellinus rimosus (Berk.) Pilát, Annls mycol. 38(1): 80. 1940.

Material examined: BRAZIL. Mato Grosso do Sul: Maracaju Mountains, Corguinho, 26-VI-2014, A.K.M. Oliveira et al. (SP466305). 
Cited for several States of Brazil (Baltazar \& Gibertoni, 2009), but not cited for Mato Grosso do Sul.

\section{Schizoporaceae}

**Schizopora paradoxa (Schrad.) Donk, Persoonia 5(1): 104.1967.

Material examined: BRAZIL. Mato Grosso do SuL: Maracaju Mountains, Corguinho, 23-V-2015, A.K.M. Oliveira et al. (SP466307).

Cosmopolitan, inedible, it is being studied in Korea within the Genome project. Cited in the list of fungi species of Brazil for several States, except for Mato Grosso do Sul (Gibertoni et al. 2015).

\section{Phallales \\ Phallaceae}

**Phallus indusiatus Vent., Mém. Inst. nat. Sci. Arts: 520.1798 .

Material examined: BRAZIL. Mato Grosso Do Sul: Maracaju Mountains, Corguinho, 12-XII-2014, A.K.M. Oliveira et. al. (SP466342).

Tropical, found in Africa, South America, Central America, Mexico and tropical Asia. It is edible and cultivated in China. It was cited for several Brazilian States (Baseia et al. 2006), but it was not previously cited for Mato Grosso do Sul.

Polyporales

Ganodermataceae

**Amauroderma omphalodes (Berk.) Torrend, Broteria, series Botany 18: 131. 1920.

Material examined: BRAZIL. Mato Grosso Do Sul: Maracaju Mountains, Corguinho, 12-XII-2014, A.K.M. Oliveira et al. (SP466308).

Known in several sites in Brazil (Campacci \& Gugliotta 2009), but it was not previously cited for Mato Grosso do Sul.

**Amauroderma schomburgkii (Mont.; Berk.) Torrend, Broteria, series botany 18: 140. 1920.

Material examined: BRAZIL. Mato Grosso do Sul: Maracaju Mountains, Corguinho, 27-VI-2014, A.K.M. Oliveira et al. (SP466309, SP466310).

Found in Cuba and South America (Furtado 1981).
**Ganoderma parvulum Murrill, Bull. Torrey Bot. Club 29: 6051902.

Material examined: BRAZIL. Mato Grosso do SuL: Maracaju Mountains, Corguinho, 12-XII-2014, A.K.M. Oliveira et. al. (SP466311).

Geographical distribution: Central America and Brazil (Meijer 2006), but it was not previously cited for Mato Grosso do Sul.

\section{Meripilaceae}

**Hydnopolyporus fimbriatus (Fr.) D.A. Reid, Persoonia 2(2): 109-170. 1962.

Material examined: BRAZIL. Mato Grosso do Sul: Maracaju Mountains, Corguinho, 12-VI-2014, A.K.M. Oliveira et. al. (SP466312).

It grows partially on alive trees. Cited in north, center-west and south of Brazil (Meijer 2008), but it was not previously cited for Mato Grosso do Sul.

\section{Meruliaceae}

**Cymatoderma dendriticum (Pers.) D.A.Reid, Kew Bull. 13(3): 523. 1959.

Material examined: BRAZIL. Mato Grosso do Sul: Maracaju Mountains, Corguinho, 23-V-2014, A.K.M. Oliveira et. al. (SP466313).

Known in several Brazilian States (Reid 1965, Meijer 2006, 2008). Cited for Mato Grosso do Sul for the first time.

*Cymatoderma elegans Jungh, Tijdschr. Nat. Gesch. Physiol. 7: 290. 1840.

Figure 14

Material examined: BRAZIL. Mato Grosso do Sul: Maracaju Mountains, Corguinho, 12-XII-2014, A.K.M. Oliveira et al. (SP466314).

Original description for Java. It has not been cited to Brasil and it is not included in the fungi list of Brazil.

Description: lignin basidiome, centrally stipitate, infundibuliform, $4 \times 5 \mathrm{~cm}$ high ,5-6 cm diâm., 0.2-0.3 cm, with serrated margin, thick stipe, solid, brown, $2-3 \times 1.5 \mathrm{~cm}$; fertile external surface, plicate (with vertical wrinkles and folds), wavy, white; pilei's internal surface is light beige to light brown, also with wrinkles and folds; dimitic hyphal system, generative hypha with thin wall, branched, septed with clamp 
connection, hyaline 3-4 $\mu$ m diâm., skeletal hyphae of very thick to solid wall, hyaline, 3.5-4 $\mu \mathrm{m}$ diâm.; ellipsoid to globous basidiospores, smooth, hyaline 2-4 × 3-4 $\mu \mathrm{m}$ diâm. On rotten wood.

Gloeoporus thelephoroides (Hook) G. Cunn., Bull. N.Z. Dept. Sci. Industr. Res. 164: 111. 1965.

Material examined: BRAZIL. Mato Grosso do SuL: Maracaju Mountains, Corguinho, 6-VI-2014, A.K.M. Oliveira et. al. (SP466345).

Cited for several Brazilian regions (Abrahão 2009, Baltazar \& Gibertoni 2009).

\section{Phanerochaetaceae}

**Irpex lacteus (Fr.) Fr., Elenchus Fungorum1: 145.1821.

Material examined: BRAZIL. Mato Grosso do Sul: Maracaju Mountains, Corguinho, on Indaiá seeds, 13XI-2014, A.K.M. Oliveira et. al. (SP466316).

Cited by Abrahão et al. (2012) for Brazilian savannah in the State of São Paulo, Pará and northeast. This is the first observation in Mato Grosso do Sul.

**Steccherinum reniforme (Berk. \& M.A. Curtis) Banker, Mem. Torrey Bot. Club 12: 127.1906.

Material examined: BRAZIL. Mato Grosso do SuL: Maracaju Mountains, Corguinho, 26-VI-2014, A.K.M. Oliveira et al. 26-VI-2014 (SP466317); 14-XI-2014, A.K.M. Oliveira et al. (SP466318).

Cited for several regions in Brazil (Baltazar \& Gibertoni 2009), but not for Mato Grosso do Sul.

\section{Polyporaceae}

*Athelopsis galzinii (Bres.) Hjortstam, Mycotaxon 42: 149. 1991.

Figure 15

Material examined: BRAZIL. Mato Grosso do SuL: Maracaju Mountains, Corguinho, 27-VI-2014, A.K.M. Oliveira et al. (SP466319).

It is the first cittation to Brazil and it is not included in the list of flora of Brazil.

Description: resupinate basidiome, white, very thin, fragile when dry, 2-3 $\times 0.1 \mathrm{~cm}$, papillate surface composed by hyphal pegs; monomytic hyphal system with branched generative hyphae, septed with clamp connection, thin wall, 2-3 $\mu$ m diâm.; basidium with clamp connection, 9-15 $\times 4-5 \mu \mathrm{m}$, 4-esterigmata; ellipsoid basidiospores, smooth, hyaline, 5-6 × 3-4 $\mu \mathrm{m}$. On rotten plants.

**Fomitopsis rosea (Alb. \& Schwein.) P. Karst., Meddn Soc. Fauna Flora fenn. 6: 9. 1881.

Material examined: BRAZIL. Mato Grosso do Sul: Maracaju Mountains, Corguinho, 26-VI-2014, A.K.M. Oliveira et al. (SP466320).

Cited in the list fungi species of Brazil for southeastern Brazil, São Paulo and Rio Grande do Sul (Baltazar \& Gibertoni 2009).

Hexagonia hydnoides (Sw.) K. Fidalgo, Mem. New York. Bot. Gard. 17: 64. 1968.

Material examined: BRAZIL. Mato Grosso do Sul: Maracaju Mountains, Corguinho, 26-VI-2015, A.K.M. Oliveira et al. (SP466321).

Known all over Brazil (Fidalgo, 1969, GomesSilva \& Gibertoni 2009).

Hexagonia variegata Berk., Annal and Magazine of Natural History, ser. 29: 196. 1852.

Material examined: BRAZIL. Mato Grosso do Sul: Maracaju Mountains, Corguinho, 23-V-2014, A.K.M. Oliveira et. al. (SP466322).

Cosmopolitan, known all over Brazil (Baltazar \& Gibertoni 2009).

Lentinus crinitus (L.) Fr., Syst. Orb. Veg. 1: 77. 1825.

Material examined: BRAZIL. Mato Grosso do Sul: Maracaju Mountains, Corguinho, 26-VI-2014, A.K.M. Oliveira et al. (SP466323); 13-XI-2014, A.K.M. Oliveira et al. (SP466324, SP466325, SP466326).

Cosmopolitan with broad distribution in Brazil (Bononi et al. 2008).

**Polyporus arcularius Batsch:Fr., Syst. Mycol. (Lundae) 1: 342. 1821.

Material examined: BRAZIL. Mato Grosso do Sul: Maracaju Mountains, Corguinho, 26-VI-2014, A.K.M. Oliveira et al. (SP466327).

Known in several Brazilian States (Abrahão et al. 2012). Cited for Mato Grosso do Sul for the first time.

**Polyporus grammocephalus Berk., Hooker's J. Bot. Kew Gard. Misc. 1: 1184. 1842.

Material examined: BRAZIL. Mato Grosso do Sul: Maracaju Mountains, Corguinho, 26-VI-2014, A.K.M. Oliveira et al. (SP466328). 
Tropical and subtropical species. It was cited for several Brazilian States (Gibertoni et al. 2004). Cited for Mato Grosso do Sul for the first time.

*Trametes ellipsospora Ryvarden, Mycotaxon 28(2): 539. 1987.

Figure 16

Material examined: BRAZIL. Mato Grosso do Sul: Maracaju Mountains, Corguinho, 23-V-2014, A.K.M. Oliveira et al. (SP466329).

Geographical distribution: Tropical America (Ryvarden 1987). It is not cited especially to Brazil and it is not included in the list of fungi species of Brazil.

Description: sessile pileate basidiome, fan-shaped, coriaceous, $4-5 \times 0.2 \mathrm{~cm}$; smooth abhymenial surface, yellowish light beige (light brown), with thinner and darker margin; porous hymenial surface, roundish pores, 2-3 for $\mathrm{mm}$, light brown to brown, darker than the abhymenial surface; coriaceous context, light beige; dimitic hyphal system; generative hyphae with thin wall, branched, septed with clamp connection, hyaline, 3-4 $\mu \mathrm{m}$ diâm.; skeletal hyphae with thickened to almost solid wall, little branched, not septed, hyaline, 3.5-4.5 $\mu \mathrm{m}$ diâm.; cylindrical basidia, 4-esterigmata, hyaline; ellipsoid almost globous basidiospores, apical, smooth, hyaline, 4-4,5 $\mu \mathrm{m}$ diâm.; cylindrical cystidia, thin wall, hyaline 10-20 $\times 2-8 \mu \mathrm{m}$. On rotten wood.

**Trametes versicolor (L.) Lloyd, Mycol. Notes (Cincinnati) 65: 1045. 1921.

Material examined: BRAZIL. Mato Grosso do SuL: Maracaju Mountains, Corguinho, 23-V-2014, A.K.M. Oliveira et al. (SP466330).

There are three polysaccharides in this species: polysaccharide K(PKS), polysaccharide-peptide (PSP) and versicolor polysaccharide (VPS). This mushroom has been used in the traditional Chinese medicine in treatments against cancer and as food supplement. It is also used in the United State. Cited for several Brazilian States (Loguercio Leite et al. 2009). Cited here for Mato Grosso do Sul for the first time.

Thelephorales

Thelephoraceae

**Thelephora paraguayensis Corner, Beihefte zur Nova Hedwigia 27: 1-110. 1968.

Material examined: BRAZIL. Mato Grosso do Sul: Maracaju Mountains, Corguinho, 26-VI-2014, A.K.M. Oliveira et al. (SP466331).
It is used in medicine (Boa 2004), collected in north and southeast of Brazil (Baltazar \& Gibertoni 2009). It was not cited for Mato Grosso do Sul before.

Tremellales

Exidiaceae

*Guepinia helvelloides (DC.) Fr., Elench. fung. (Greifswald) 2: 30. 1828.

Figure 17

Material examined: BRAZIL. Mato Grosso do Sul: Maracaju Mountains, Corguinho, 26-VI-2014, A.K.M. Oliveira et. al. (SP466332).

It is edible and medicinal (Shen et al. 2009). It was not cited to Brasil and it is not included in the list of species of fungi of Brazil.

Description: club-shaped basidiome, forked at the top, meaty, flexible, smooth surface, sometimes inner surfaces have warts, salmon pink; stipe non differentiated from the pilei, which is more cartilaginous with whitish base, 4-5 × 3-4 cm; hyaline basidium divided into ovoid hypobasidia 12-16 $\times$ 9-12 $\mu \mathrm{m}$ and elongate epibasidia 20-40 $\times 3-4 \mu \mathrm{m}$; cylindrical basidiospores, smooth, hyaline with a large oil drop, 9-11 $\times 3-4 \mu \mathrm{m}$. Isolate or in groups, in the soil associated to wood.

\section{Tremellaceae}

*Tremella mesenterica Retz, K. Svenska Vetensk/ Akad. Handl. 30: 249. 1769.

Figure 18

Material examined: BRAZIL. Mato Grosso DO Sul: Maracaju Mountains, Corguinho, 12-XII-2014, A.K.M. Oliveira et. al. (SP466333).

Tropical distribution: Africa, Australia, Europe, North and South America. It is not mentioned in the list of fungi species of Brazil, and specially to Brasil. Edible, it has polysaccharides that act in the immune system, anti-diabetes, anti-inflammatory, anti-cholesterol, in addition to protecting the liver and being anti-allergies (Vinogradov et al. 2004).

Description: sessile basidiome, irregularly lobed to cerebriform, gelatinous when fresh and hard when dry, orange-yellow, smooth surface, $3-7.5 \mathrm{~cm}$ diâm., 2.5-5 cm high; sometimes stiptated; basidia ellipsoid to globous with 4 vertical septs, $15-21 \times 12-18 \mu \mathrm{m}$; basidiospores, smooth, 10-16 $\times 6-9.5 \mu \mathrm{m}$. On rotten wood. 


\section{Discussion}

The region researched is a zone of transition from plateau to flat land in Pantanal, a place periodically flooded, with species that have not been described for the place and for Brazil, indicating its potential for study. The finding of 18 new specifies of macroscopic fungi for Brazil shows the lack of local knowledge and also how limited the number of experts who research this biome is.

Once the assessment lasted a limited period of time, it probably does not exhaust the number of species present in the region and other may come to be found. The majority of the species cited for the first time are ephemeral and, therefore, harder to find. However, more perennial species, such as Fomitiporia robusta, Cymatoderma elegans, Atheliopsis galzinii and Trametes ellipsospora have also been identified for the first time in Brazil.

Molecular studies of the new Agaricomycetes species from Brazil with commercial kits were tried but were unsucessfull, probably because the drying and conservation techniques. New approaches with manual DNA extraction are being tested and vouchers of these materials are available at the SP Herbarium.

Among the species collected, Neonothopanus gardnerii, a bioluminescent and edible species with preference on palm trees and found in several places in Brazil, can be highlighted. Hydnochaete badia, on the other hand, is a species described and known only in Brazil, probably endemic. But this paper broadens its area of geographical distribution.

Once work of environmental education and ecotourism are developed in the region, we tried to identify species of interest and to inform in the text whether they are edible, their medicinal use and applications in biotechnological processes.

\section{Conclusion}

This paper contributes to the knowledge to the mycota of Agaricomycetes of the region Planalto da Serra de Maracajú and of Brazil, broadening the knowledge of the geographical distribution of fiftyfour fungi species. Fungi with potential economic interest are available in the area studied.

\section{Literature cited}

Abrahão, M.C., Gugliotta, A.M. \& Gomes, E. 2009. Poliporóides (Basidiomycota) em fragmentos de mata no perímetro urbano de São José do Rio Preto, São Paulo, Brasil. Revista Brasileira de Botânica 32: 427-440.
Abrahão, M.C., Gugliotta, A.M. \& Bononi, V.L.R. 2012. Xylophilous Agaricomycetes (Basidiomycota) of Brazilian Cerrado. Check List 8: 1102-1116.

Antonin, V. \& Nordeloos, M.E. 2010. A monograph of marasmioid and collybioid fungi in Europe. IHWVerlag, Eching, Germany.

Bae, J.S., Jang, K.H., Yim, H. \& Jin, H.K. 2005. Polysaccharides isolated from Phellinus gilvus inhibit melanoma growth in mice. Cancer Letter 218: 43-52.

Baltazar, J.M. \& Gibertoni, T.B. 2009. A checklist of the aphyllophoroid fungi (Basidiomycota) recorded from the Brazilian Atlantic Forest. Mycotaxon 109: 439-442.

Baseia, I.G. 2005. Bovista (Lycoperdaceae): dois novos registros para o Brasil. Acta Botanica Brasilica 19: 899-903.

Baseia, I.G. \& Goes-Neto, A. 2006. Filo Basidiomycota. In: L.F.P. Gusmão \& L.C. Maia (org.). Diversidade e caracterização dos fungos do semi-árido brasileiro. Associação Plantas do Nordeste (APNE), Recife, v. 2, pp 141-159.

Baseia, I.G., Maia, L.C. \& Calonge, F.D. 2006. Notes on the Phallales in Neotropics. Boletín de la Sociedad Micologica de Madrid 30: 87-93.

Baseia, I.G. \& Milanez, A.I. 2001a. Crucibulum laeve (Huds.) Kambly in cerrado vegetation of São Paulo State, Brazil. Acta Botanica Brasilica 15: 13-16.

Baseia, I.G. \& Milanez, A.I. 2001b. Nidularia pulvinata (Schwein.) Fries (Gasteromycetes): a new record from Brazil. Revista Brasileira de Botânica 24: 479-481.

Baseia, I.G. \& Milanez, A.I. 2002a. Montagnea haussknechtii Rab. (Podaxales) a rare agaricoid fungus: first record from Brazil. Acta Botanica Brasilica 16: 311-315.

Baseia, I.G. \& Milanez, A.I. 2002b. Tulostoma (Gasteromycetes) from the cerrado region, State of São Paulo, Brazil. Acta Botanica Brasilica 16: 9-14.

Baseia, I.G. \& Milanez, A.I. 2003. Cyathus (Gasteromycetes) in areas of the Brazilian cerrado region, São Paulo State. Mycotaxon 80: 493-502.

Baseia, I.G., Silva, B.D.B., Leite, A.G.\& Maia, L.C. 2007. $\mathrm{O}$ gênero Calostoma (Boletales, Agaricomycetidae) em áreas de Cerrado e semi-árido no Brasil. Acta Botanica Brasilica 21: 277-280.

Becker, H.F., Motorin,Y., Planta, R.J. \& Grosjean, H. 1997. The yeast gene YNL291w encodes a pseudopurine synthase(Pus4) catalyzing the formation of psi55 in both mitochondrial and cytoplasmic ERNAs. Nuclei Acids Research 25: 4493-4499.

Bononi, V.L.R. 1984. Basidiomicetos do Parque Estadual da Ilha do Cardoso. IV. Adições às famílias Hymenochaetaceae, Stereaceae e Thelephoraceae. Rickia 11:43-52.

Bononi, V.L.R. 1988. Hydnoid fungi from Tropical America. In: The Aphyllophorales Symposium, 27 September to 1 October 1982. Eisenstad-Austria. Proceedings. 
Bononi, V.L.R., Oliveira, A.K.M., Quevedo, J.R. \& Gugliotta, A.M. 2008. Fungos macroscópicos do Pantanal do rio Negro, Mato Grosso do Sul. Hoehnea 35: 35-91.

Campacci, T.V.S. \& Gugliotta, A.M. 2009. A review of Amauroderma in Brazil, with the new record of A. oblongisporum in the neotropics. Mycotaxon 110: 423-436.

Canhos, V.P. 1997. Disseminação de Informação: O Uso da Internet. In: I. Garay, B.F.S. Dias. (org.). Conservação da Biodiversidade em Ecossistemas Tropicais: Avanços Conceituais e Revisão de Metodologias de Avaliação e Monitoramento. Vozes, São Paulo.

Capelari, M. 1989. Agaricales do Parque Estadual da Ilha do Cardoso (exceto Tricholomataceae). Dissertação de Mestrado, Universidade de São Paulo, São Paulo.

Capelari, M. \& Maziero, R. 1988. Two new species of Agaricales from Brazil. Mycotaxon 33: 191-196.

Capelari, M., Desjardin, D.E., Perry, B.A., Asai, T. \& Stevani, C.V. 2011. Neonothopanus gardneri: a new combination for a bioluminescent agaric from Brazil. Mycologia 103: 1433-1440.

Chen, J. 1995. Development of fungal degrading system to detoxify 2,4,6-trinitrotoluene (TNT) in liquid phase bioreactors. PhD dissertation, Texas A\&M University.

Corner, E.J.H. 1950. A monograph of Clavaria and allied genera. Annals of Botany Memoirs 1: 17-740.

Drechsler-Santos, E.R., Groposo, C. \& Loguercio-Leite, C. 2008. Additions to the knowledge of lignocellulolytic Basidiomycetes (Fungi) in forests from Santa Catarina Southern Brazil. Mycotaxon 103: 197-200.

Drechsler-Santos, E.R., Gibertoni, T.B., Goes-Neto, A. \& Cavalcanti, M.A.Q. 2009. A re-evaluation of the lignocellulolytic Agaricomycetes from the Brazilian semi-arid region. Mycotaxon 108: 241-244.

Efremenkova, O.V., Eeshova, E.Y., Tolstych, I.V., Zenkova, V.A. \& Dudnik, Y.V. 2003. Antimicrobial activity of medicinal mushrooms from the genus Coprinus (Fr.) S.F. Gray (Agaricomycetideae). International Journal of Medicinal Mushrooms 5: 37-41.

Elekes, C.C. \& Busuioc, G. 2010. The Mycoremediation of Metals Polluted Soils Using Wild Growing Species of Mushrooms. Engineering Education. Available in http://www.wseas.us/e-library/conferences/2010/ Corfu/EDUCATION/EDUCATION-04.pdf (access in 20-XI-2015).

Eyssatier, G. \& Roux, P. 2013. Le Guide des Champignons France et Europe . Belin, Paris.

Estrada, A.E.R. \& Royse, D.J. 2008. Pleurotus eryngii and P. nebrodensis: from the wild to commercial production. Mushroom News.

Fidalgo, M.E.P.K. 1968. The genus Hexagona. Memoirs of the New York Botanical Garden 17: 35-108.

Fidalgo, O. \& Bononi, V.L.R. (org.). 1984. Técnicas de coleta, preservação e herborização de material botânico. Manual n.4. Instituto de Botânica, São Paulo.
Fidalgo, O., Fidalgo, M.E.P.K. \& Furtado, J.S. 1965. Fungi of the "cerrado" region of São Paulo. Rickia 2: 55-71.

Furtado, J.S. 1981. Taxonomy of Amauroderma (Basidiomycetes, Polyporaceae). Memoirs of the New York Botanical Garden 34: 1-109.

Gibertoni, T.B. \& Drechsler-Santos, E.R. 2010. Lignocellulolytic Agaricomycetes from the Brazilian Savannah biome. Mycotaxon 111: 87-90.

Gilbertson, R.L. \& Ryvarden, L. 1986. North American Polypores. Fungiflora 1: 1-433.

Gomes-Silva, A.C. \& Gibertoni, T.B. 2009. Revisão do Herbário URM. Novas ocorrências de Aphyllophorales para a Amazônia brasileira. Revista Brasileira de Botânica 32: 587-596.

Gugliotta, A.M. 1997. Polyporaceae de mata ciliar da Estação Experimental e Reserva Biológica de MojiGuaçu, São Paulo, Brasil. Hoehnea 24: 89-106.

Gugliotta, A.M., Gibertoni, T.B., Drechsler-Santos, E.R., Silveira, R.M.B., Chikowski, R.S., Pires R.M., Montoya, C.A.S., Souza, J.F., Palacio, M. \& Rezende, D.H.C. 2015. Polyporales in Lista de Espécies da Flora do Brazil. Jardim Botânico do Rio de Janeiro. Available in http://reflora.jbrj. gov.br/jabot/floradobrasil/FB92492 (access in 16-V-2015).

Guzmán, G. 1978. The species of Psilocybe known from Central and South America. Mycotaxon 7: 225-255.

Hibbett, D.S. \& Donoghue, M.J. 1995. Progress toward a phylogenetic classification of the Polyporaceae through parsimony analysis of mitochondrial ribosomal DNA sequences. Canadian Journal of Botany 73: 853-861.

Hibbett, D.S. \& Thorn, R.G. 2001. Basidiomycota: Homobasidiomycetes. In: K. Esser, P.A. Lemke (ed.). The Mycota VII Part B: Systematic and Evolution. Springer/Verlag, Berlin.

Hibbett, D.S., Nilsson, R.H., Snyder, M., Fonseca, M.J., Costanzo, M. \& Shonfeld, M. 2005. Automated Phylogenetic Taxonomy: an example in the Homobasidiomycetes (Mushroom/Forming Fungi). Systematic Biology 54: 660-668.

Hibbett, D.S., Binde, M., Bischoff, J.F., Blackwel, M., Cannon, P.F., Eriksson, O.E., Huhndorf, S., James, T., Kirk, P.M., Lücking, R., Thorsten, H., Lutzoni, F., Matheny, P.B., McLaughlin, D.J., Powell, M.J., Redhead, S., Schoch, C.L., Spatafora, J.W., Stalpers, J.A., Vilgalys, R., Aime, M.C., Aptroot, A., Bauer, R., Begerow, D., Benny, G.L., Castlebury, L.A., Crous, P.W., Dai, Y.C., Gams, W., Geiser, K., Griffith, D.M., Gueidan, C., Hawksworth, D.L., Hestmark, G., Hosaka, R., Humber, A., Hyde, K.D., Ironside, J.E., Kõljalg, U., Kurtzman, C.P., Larsson, K.H., Lichtwardt, R., Longcore, J., Miadlikowska, J., Miller, A., Moncalvo, J.M., MozleyStandridge, S., Oberwinkler, F., Parmasto, E., Reeb, V., Rogers, J.D., Roux, C. , Ryvarden, L., Sampaio, J.P., Schübler, A., Sugiyama, J., Thorn, R.G., Tibell, L., Untereiner, W.A., Walker, C., Wang, Z., Weir, A., Weiss, M., White, M.M., Winka, K., Yao, Y.J.\& Zhang, N. 2007. A higher level phylogenetic classification of the Fungi. Mycological Research 111: 509-547. 
Jesus, M.A. 1996. Contribution to the knowledge of woodrotting fungi in Brazil. II. A checklist of wood-rotting fungi from Maraca Island, Roraima, Brazil. Mycotaxon 42: 323-328.

Joly, A.C. \& Bicudo, C.E. (org.). 1998. Biodiversidade do Estado de São Paulo: síntese do conhecimento ao final do século XX, Fundação de Amparo à Pesquisa do Estado de São Paulo - FAPESP, São Paulo.

Jordan, M. 2004. The encyclopedia of fungi of Britain and Europe. Frances Lincoln Ltd, London.

Kasuya, T., Orihara, T., Fukihara, T. \& Yoshimi, S. 2006. A Lycoperdaceous fungus, Arachnion album (Agaricales, Arachniacea), newly found in Japan. Mycoscience 47: 385-387.

Kirk, P.M., Cannon, P.F., Minter, D.W. \& Stalpers, J.A. 2008. Ainsworth and Bisby's Dictionary of the Fungi. CAB International, Wallingford.

Leon, P.P. 1971. Revision of Genus Morganella (Lycoperdaceae). Fieldiana Botany 31: 27-44.

Lincoff, G.H. 1981. National Audubon Society Field Guide to North American Mushrooms. Knopf, New York.

Loguercio-Leite, C., Campos-Santana, M., Gerlach, A., Gutjahr, M., Trieveler-Pereira, L., Drechsler-Santos, E.R. \& Baltazar, J.M. 2009. Résumé of macromycetes from Santa Catarina State, Southern Brazil. Ínsula 38: 1-14.

Maia, L.C. \& Carvalho Jr., A.A. 2015. Fungos. In: Lista de Espécies da Flora do Brazil. Jardim Botânico do Rio de Janeiro. Available in http://floradobrasil.jbrj.gov.br (access in 12-VII-2015).

Massee, G.E. 1899. The fungus flora of New Zealand. Transactions and Proceedings of the New Zealand Institute 31: 282-349.

Matheus, D.R. 1998. Biorremediação de solos contaminados com compostos organoclorados e biodegradação de hexaclorobenzeno por basidiomicetos brasileiros. Dissertação de Mestrado, Universidade Estadual Paulista, Rio Claro.

Secretaria de Planejamento e Coordenação Geral de Mato Grosso do Sul. 1990. Atlas multirreferencial. Mapas. Governo do Estado do Mato Grosso do Sul, Campo Grande.

Meijer, A.A.R. 2006. Preliminary list of the macromycetes from the Brazilian State of Paraná. Boletim do Museu Botânico Municipal de Curitiba 68: 1-59.

Meijer, A.A.R. 2008. Notable Macrofungi from Brazil's Paraná Pine Forest. Embrapa Floresta, Colombo.

Menolli Jr., N., Breternitz, B. \& Capelari, M. 2014. The genus Pleurotus in Brazil: a molecular and taxonomic overview. Mycoscience 55: 378-389.
Mittermeier, R.A., Gil, P.R., Hoffmann, M., Pilgrim, J., Brooks, T., Mittermeier, C.G., Lamoreux, J. \& Fonseca, G.A.B. 2005. Hotspots revisited: Earth's biologically richest and most endangered terrestrial ecoregions. CEMEX, Mexico City.

Morrone, J.J. 2001. Biogeografía de América Latina y el Caribe. M\&T-Manuales \& Tesis. SEA, Zaragoza.

Myers, N., Mittermeier, R., Mittermeier, C.G., Fonseca, G.A.B.\& Kent, J. 2000. Biodiversity hotspots for conservation priorities. Nature 403: 853-858.

Pacheco- Sanchez, M., Boutin, Y., Angers, P., Gosselin, A. \& Tweddel, R.J. 2006. A bioactive (1-->3)-, (1--4)-beta-D-glucan from Collybia dryophila and other mushrooms. Mycologia 98: 180-185.

Pegler, D.N. 1997. The Agarics of São Paulo, Brazil. Royal Botanic Gardens, Kew.

Pott, A. \& Pott, V.J. 2000. Plantas aquáticas do Pantanal. Embrapa, Brasília.

Prado, J. \& Marcelli, M.P. 2008. Criptógamas. In: R.R. Rodrigues, V.L.R. Bononi (ed.). Diretrizes para a Conservação e Restauração da Biodiversidade no Estado de São Paulo. Instituto de Botânica, São Paulo.

Puccinelli, C. \& Capelari, M. 2009. Marasmius (Basidiomycota - Marasmiaceae) do Parque Estadual das Fontes do Ipiranga, São Paulo, SP, Brasil: seção Sicci .Hoehnea 36: 637-655.

Ramesh, C. \& Pattar, M.G. 2010. Antimicrobial properties, antioxidant activity and bioactive compounds from six wild edible mushrooms of western ghats of Karnataka, India. Pharmacognosy Research 2: 107-12.

Reid, D.A. 1965. A monograph of stipitate steroid fungi. Beih. Nova Hedwigia 18: 1-382.

Rick, J. 1937. Agarici riograndensis. Lilloa 1: 307-346.

Rick, J. 1961. Basidiomycetes Eubasidii in Rio Grande do Sul, Brasilia. Iheringia, série Botânica. 8: 296-450.

Ruegger, M.J.S., Tornisielo, S.M.T., Bononi, V.L.R. \& Capelari, M. 2001. Cultivation of the edible mushroom Oudemansiella canarii (Jungh.) Höhn. In: lignocellulosic substrates. Brazilian Journal of Microbiology 32: 211-214.

Ryvarden, L. 1991. Genera of Polypores. Nomenclature and Taxonomy. Synopsis Fungorum 5: 1-363.

Ryvarden, L. 2004. Neotropical Polypores. Part 1. Introduction, Ganodermataceae and Hymenochaetaceae. Synopsis Fungorum 19: 1-22.

Sampaio, A.J. 1916. A flora de Matto Grosso. Arquivos do Museu Nacional 19: 1-127.

Shen, Q., Chen, W., Yan, Z.\& Xie, Z. 2009. Potential pharmaceutical resources of the Qinling Mountain in central China: medicinal fungi. Frontiers of Biology in China 4: 89-93. 
Silveira, R.M.B. 2015. Auriculariales. In: Lista de Espécies da Flora do Brazil. Jardim Botânico do Rio de Janeiro. Available in http://floradobrasil.jbrj.gov.br (access in 12-VII-2015).

Singer, R. 1976. Marasmiae (Basidiomycetes/ Tricholomataceae). Flora Neotropica Monograph 17: 1-147.

Stamets, P. 2014. Integrative fungal solutions for protecting bees and overcoming colony collapse disorder (CCD): methods and compositions.US 20140220150 A1 (patent).

Teixeira, A.R. 1945. Himenomicetos brasileiros: Hymeniales - Thelephoraceae. Bragantia 5: 397434.

Teixeira, A.R. 1962. The taxonomy of the Polyporaceae. Biological Reviews 37: 51-81.
Teixeira, A.R. 1995. Método para estudo das hifas do basidiocarpo de fungos poliporáceos. Manual n. 6 . Instituto de Botânica, São Paulo.

Vellinga, E.C., Kok, R.P.J.\& Bruns, T.D. 2003. Phylogeny and taxonomy of Macrolepiota (Agaricaceae). Mycologia 95: 442-56.

Vinogradov, E., Petersen, B.O., Duus, J.O. \& Wasser, S.P. 2004. The isolation, structure, and applications of the exocellular heteropolysaccharide glucuronoxylomannan produced by yellow brain mushroom Tremella mesenterica Ritz.:Fr. (Heterobasidiomycetes). International Journal of Medicinal Mushrooms 6: 335-345.

Wagner, T. \& Fischer, M. 2002. Proceedings towards a natural classification of the worldwide taxa Phellinus s.l. and Inonotus s.l., and phylogenetic relationships of allied genera. Mycologia 94: 998-1016. 